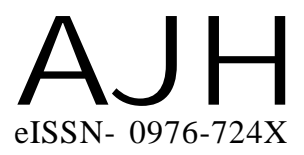

Received : 10.07.2014

Revised : 19.10.2014

Accepted : 01.11.2014

Members of the Research Forum

Associated Authors:

${ }^{1}$ Regional Research Station,

Agwanpur, SAHARSA(BIHAR) INDIA

${ }^{2}$ Krishi Vigyan Kendra, KATIHAR (BIHAR) INDIA
Author for correspondence : AJAY KUMAR DAS

Krishi Vigyan Kendra, KATIHAR (BIHAR) INDIA

Email : eshusao@gmail.com
THE ASIAN JOURNAL OF HORTICULTURE

Volume 9 | Issue 2 |Dec., 2014 |372-376

Visit us -www.researchjournal.co.in

\title{
Response of chemical fertilizer and vermicompost on okra (Abelmoschus esculantus) cv. PRAVANI KRANTI
}

\section{AJAY KUMAR DAS, BIRENDRA PRASAD ${ }^{1}$ AND RAMAKANT SINGH ${ }^{2}$}

ABSTRACT : A field experiment was conducted to study the response of chemical fertilizer and vermicompost on okra (Abelmoschus esculentus L.) var. Pravani kranti. The experiment was laid out in a RBD with five treatments each replicated ten. The treatments involved was $\mathrm{T}_{1}-100$ per cent chemical fertilizer +0 per cent vermincompost, $T_{2}-75$ per cent chemical fertilizer +25 per cent vermincompost, $\mathrm{T}_{3}-50$ per cent chemical fertilizer +50 per cent vermicompost, $\mathrm{T}_{4}-25$ per cent chemical fertilizer +75 per cent vermincompost, and $\mathrm{T}_{5}-0$ per cent chemical fertilizer +100 per cent vermincompost. The results revealed that the application of $\mathrm{T}_{3}$ had a significant effect on growth and yield of okra. Field experiment showed that maximum plant height $(106.13 \mathrm{~cm})$, node per plant $(7.75)$, pod per plant (18.65), pod yield per plant $(149.46 \mathrm{~g})$, length of pod $(17.60 \mathrm{~cm}), 50$ per cent flower initiation (40 DAS) and yield per ha $(110.24 \mathrm{q})$ were produced with $\mathrm{T}_{3}$ whereas number of seed per pod were found with the $T_{1}$. Vermicompost can increase growth, flowering and yield of vegetable. Vermicompost applied at very low rate $2.5-5$ ton / ha can significantly increase yield of highly valuable vegetable and fruit crops. Vermicompost enhance the quality of soil by enhancing microbial biomass which are key component in nutrients recycling, production of PGR and protecting plants from soil borne disease (Pascual et al., 1997). Combination of vermicompost and inorganic chemical fertilizer resultant in maximum number of flowers and pods of okra plants. Hence, the application of appropriate ratio of vermicompost and chemical fertilizers in the field they acts as growth promoter for okra. Proper combination least damage the soil and help to maintain its fertility for a longer period.

KEY WORDS : Abelmoschus esculantus, Pravani kranti, Chemical fertilizer, Vermicompost

HOW TO CITE THIS ARTICLE : Das, Ajay Kumar, Prasad, Birendra and Singh, Ramakant (2014). Response of chemical fertilizer and vermicompost on okra (Abelmoschus esculantus) cv. PRAVANI KRANTI. Asian J. Hort., 9(2) : 372-376. 